\section{Quest for pharmacotherapy in aortic valve stenosis: the lipid hypothesis}

\author{
Kang H Zheng (i) , ${ }^{1}$ Marc R Dweck ${ }^{2}$
}

Aortic stenosis was first described by the French surgeon and anatomist Lazare Riviere in 1663. While the last decade has seen impressive advances in our ability to treat aortic valve stenosis invasively and percutaneously, significant issues remain with regards to the optimal timing of valve replacement, periprocedural risks and long-term durability. There therefore remains major interest in developing medical treatments to halt or slow progression of aortic stenosis, which could obviate the need for surgical intervention altogether. A stitch in time saves nine; however, no pharmacotherapies are currently proven to be effective for the treatment of calcific aortic valve stenosis (CAVS).

Atherogenic apolipoprotein B-containing lipoproteins, such as low-density lipoprotein (LDL) and lipoprotein(a) $(\mathrm{Lp}(\mathrm{a}))$, have clearly been implicated in the pathogenesis of aortic stenosis, particularly in the early initiation phase. However, LDL cholesterol lowering with statins or ezetimibe failed to modify progression of aortic valve stenosis in multiple randomised clinical trials (SEAS, SALTIRE and ASTRONOMER). Attention has instead switched to $\operatorname{Lp}(\mathrm{a})$, with a growing body of epidemiology, genetics and prospective imaging studies having built a convincing case for elevated $\mathrm{Lp}(\mathrm{a})$ levels being associated with an increased incidence of aortic stenosis, increased disease activity, faster disease progression and the more rapid need for aortic valve replacement. ${ }^{1}$ Although the pathophysiological mechanisms are still incompletely understood, the procalcific effect of $\mathrm{Lp}$ (a) has so far been attributed to its content of oxidised phospholipids (OxPL). One potential mechanism is that the enzyme lipoprotein-associated phospholipase A2 (Lp-PLA2), which binds to plasma lipoproteins including LDL and $\mathrm{Lp}(\mathrm{a})$, transforms OxPLs into lysophosphatidylcholine (lysoPC). In turn,

\footnotetext{
'Department of Vascular Medicine, Amsterdam University Medical Centers, Amsterdam, North Holland, Netherlands

${ }^{2}$ British Heart Foundation Centre for Cardiovascular Science, University of Edinburgh, Edinburgh, UK
}

Correspondence to Dr Kang $\mathrm{H}$ Zheng, Department of Vascular Medicine, Amsterdam UMC, AMC, Amsterdam, The Netherlands; k.h.zheng@amsterdamumc.nl
lysoPC is converted by the enzyme autotaxin to lysophosphatidic acid, which has been demonstrated to induce calcification in experimental models through an inflammation-mediated pathway. ${ }^{2}$

In this issue of Heart, Perrot and colleagues perform a deep dive into this putative mechanism and the role of Lp-PLA2 in humans. Previously, their lab demonstrated that Lp-PLA2 is highly expressed in diseased aortic valves, and plasma Lp-PLA2 activity was associated with faster disease progression in patients with mild aortic stenosis. ${ }^{34}$ In their current report, they first take advantage of their well-characterised biobank of patients undergoing cardiac surgery. Confirming previous findings, they demonstrate that Lp-PLA2 activity is increased in patients with CAVS as compared with patients with coronary artery disease, although this difference was minimal. In support, higher Lp-PLA2 activity was also associated with CAVS when adjusted for multiple risk factors.

Next, they used the power of genetic association studies to probe whether variants at the gene coding for Lp-PLA2 activity (PLA2G7 locus) were associated with calcific aortic valve stenosis in a very large-scale dataset. The goal of these Mendelian randomisation analyses is to assess the effect of life-long exposure to-in this case-elevated Lp-PLA2 activity, thereby providing an unconfounded estimate of the effect of Lp-PLA2 activity on CAVS risk. Collaborating with colleagues from Europe and the USA, they were able to combine eight cohorts of European descent and accrue an impressive number of 10137 CAVS cases and 434585 controls. Nevertheless, they did not find an association between any Lp-PLA2 activity raising variant at the PLA2G7 locus and CAVS, nor an association with aortic valve CT calcium scores in the CHARGE consortium. These findings conclude that Lp-PLA2 is not a causal risk factor for CAVS but a biomarker at best.

Where does this study leave us? Given the growing healthcare burden of CAVS, there is a clear need to better understand the underlying disease mechanisms in order to help identify potential biological targets. ${ }^{5}$ Strong evidence points towards elevated $\mathrm{Lp}(\mathrm{a})$ levels and its associated OxPL as causal risk factors for CAVS, suggesting that targeting this lipid-driven, inflammatory pathway has a real chance to translate into therapy capable of mitigating disease. The current study suggests that this association is not mediated by Lp-PLA2 and underlines the importance of scrutinising whether biological factors within pathophysiological pathways are merely biomarkers or actually represent a feasible and causal target. More direct targeting of $\mathrm{Lp}(\mathrm{a})$ and OxPL would therefore appear to hold more potential as an effective treatment strategy. Emerging antisense oligonucleotides are capable of potently lowering $\mathrm{Lp}$ (a) levels in patients and are currently being tested in cardiovascular outcome trials in atherosclerosis. ${ }^{6}$ Similar randomised controlled trials are patiently awaited in CAVS. Indeed, while observation studies are of value in improving our understanding of the biology of aortic stenosis and in helping us to select the most promising targets for further investigation, randomised

\begin{tabular}{|c|c|c|}
\hline Study & Target & Treatment \\
\hline \multicolumn{3}{|l|}{ Lipid-driven inflammation pathways } \\
\hline $\begin{array}{l}\text { PCSK9 inhibitors in the progression of aortic stenosis } \\
\text { (NCT03051360) }\end{array}$ & $\begin{array}{l}\text { ApoB-containing } \\
\text { lipoproteins; PCSK9. }\end{array}$ & $\begin{array}{l}\text { Biweekly injection of PCSK9 } \\
\text { inhibitor versus placebo. }\end{array}$ \\
\hline $\begin{array}{l}\text { EAVaLL - Early Aortic Valve Lipoprotein (a) Lowering } \\
\text { (NCT02109614) }\end{array}$ & Lipoprotein(a). & $\begin{array}{l}\text { Daily extended-release niacin } \\
1500-2000 \mathrm{mg} \text { versus placebo. }\end{array}$ \\
\hline \multicolumn{3}{|l|}{ Calcification pathways } \\
\hline $\begin{array}{l}\text { SALTIRE II - Study Investigating the Effect of Drugs } \\
\text { Used to Treat Osteoporosis on the Progression of } \\
\text { Calcific Aortic Stenosis } \\
\text { (NCT02132026) }\end{array}$ & Mineral metabolism. & $\begin{array}{l}\text { Alendronic acid }(n=50) \\
\text { versus placebo tablets } \\
(n=25) . \\
\text { Denosumab }(n=50) \text { versus } \\
\text { placebo injections }(n=25) .\end{array}$ \\
\hline $\begin{array}{l}\text { BASIK2 - Bicuspid Aortic Valve Stenosis and the Effect } \\
\text { of vitamin K2 on Calciummetabolism on 18F-NaF PET/ } \\
\text { MRI } \\
\text { (NCT02917525) }\end{array}$ & $\begin{array}{l}\text { Vitamin K2-Matrix Gla } \\
\text { protein. }\end{array}$ & $\begin{array}{l}\text { Daily vitamin K2 } 360 \mu g(n=22) \\
\text { versus placebo }(n=22) .\end{array}$ \\
\hline
\end{tabular}


controlled trials are ultimately required to provide definitive evidence of efficacy. These studies are both time consuming and relatively expensive, but the potential market for an effective treatment for aortic stenosis is huge and unburdened by any effective competitors. Several such RCTs currently underway (table 1), as some 353 years after its first description we still patiently await an effective medical treatment for aortic stenosis.

Twitter Kang H Zheng @Zheng_KH and Marc R Dweck@MarcDweck

Contributors Both authors contributed equally.

Funding The authors have not declared a specific grant for this research from any funding agency in the public, commercial or not-for-profit sectors.

Competing interests None declared.

Patient and public involvement Patients and/or the public were not involved in the design, or conduct, or reporting, or dissemination plans of this research.

Patient consent for publication Not required.

Provenance and peer review Not commissioned; externally peer reviewed.

\section{(2) \\ OPEN ACCESS}

Open access This is an open access article distributed in accordance with the Creative Commons Attribution Non Commercial (CC BY-NC 4.0) license, which permits others to distribute, remix, adapt, build upon this work non-commercially, and license their derivative works on different terms, provided the original work is properly cited, appropriate credit is given, any changes made indicated, and the use is non-commercial. See: http:// creativecommons.org/licenses/by-nc/4.0/.

(c) Author(s) (or their employer(s)) 2020. Re-use permitted under CC BY-NC. No commercial re-use. See rights and permissions. Published by BMJ.

\section{(A) Check for updates}

To cite Zheng KH, Dweck MR. Heart 2020;106:1376-1377.

Published Online First 7 July 2020

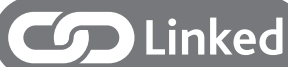

- http://dx.doi.org/10.1136/heartjnl-2020-316722
Heart 2020;106:1376-1377.

doi:10.1136/heartjnl-2020-317188

ORCID iD

Kang H Zheng http://orcid.org/0000-0001-8954-1337

\section{REFERENCES}

1 Zheng KH, Tsimikas S, Pawade T, et al. Lipoprotein(a) and Oxidized Phospholipids Promote Valve Calcification in Patients With Aortic Stenosis. J Am Coll Cardiol 2019:73:2150-62.

2 Bouchareb R, Mahmut A, Nsaibia MJ, et al. Autotaxin Derived From Lipoprotein(a) and Valve Interstitial Cells Promotes Inflammation and Mineralization of the Aortic Valve. Circulation 2015:132:677-90.

3 Capoulade R, Mahmut A, Tastet L, et al. Impact of plasma Lp-PLA2 activity on the progression of aortic stenosis: the PROGRESSA study. JACC Cardiovasc Imaging 2015;8:26-33.

4 Nsaibia MJ, Boulanger M-C, Bouchareb R, et al. OxLDLderived lysophosphatidic acid promotes the progression of aortic valve stenosis through a LPAR1-RhoA-NF-KB pathway. Cardiovasc Res 2017;113:1351-63.

5 Zheng KH, Tzolos E, Dweck MR. Pathophysiology of aortic stenosis and future perspectives for medical therapy. Cardiol Clin 2020;38:1-12.

6 Tsimikas S, Karwatowska-Prokopczuk E, GouniBerthold I, et al. Lipoprotein(a) Reduction in Persons with Cardiovascular Disease. N Eng/ J Med 2020:382:244-55. 